\title{
The Nonlinear Effect of Public Debt on Economic Growth in Jordan over the Period 1980 - 2018
}

\author{
Eman Abdel Khalek Fseifes ${ }^{1,}$, Talib Mohammad Warrad ${ }^{2}$ \\ ${ }^{1}$ Department of Business Economics, School of Graduate Studies, University of Jordan, Amman, Jordan \\ ${ }^{2}$ Department of Business Economics, School of Business, University of Jordan, Amman, Jordan
}

Email address:

iman.fseifes@gmail.com(E. A. K. Fseifes), talibawad@yahoo.com(T. M. Warrad)

${ }^{*}$ Corresponding author

\section{To cite this article:}

Eman Abdel Khalek Fseifes, Talib Mohammad Warrad. The Nonlinear Effect of Public Debt on Economic Growth in Jordan over the Period 1980 - 2018. International Journal of Business and Economics Research. Vol. 9, No. 2, 2020, pp. 60-67. doi: 10.11648/j.ijber.20200902.11

Received: February 1, 2020; Accepted: February 17, 2020; Published: February 25, 2020

\begin{abstract}
At reasonable levels, public debt enhances growth and promotes welfare. However, at high levels it turns out to be detrimental. When does the effect of public debt change from good to bad? To address this question locally, this study investigates empirically the long-run relationship between public debt and economic growth in Jordan, using time series data over the period 1980 - 2018. The modeling of the debt-growth relationship is based on theoretical arguments and empirical considerations and analyzed by adopting both linear and non-linear specifications. The model is estimated by fully modified ordinary least squares (FM-OLS) approach, the empirical results confirm that public debt is negatively associated with economic growth in the long-run. On the other hand, investment, labor force growth, and openness of trade are found to be positively associated with economic growth in the long-run. There is an evidence of non-linearity between public debt and economic growth in the long-run, with only high levels of debt exceeding 78 percent of GDP, having a significant negative effect on growth. This result demonstrates an inverted U-shaped curve in the debt-growth relationship in Jordan, in other words, the direction of the effect of public debt on economic growth transforms smoothly from positive to negative depending on the level of indebtedness. Accordingly this study emphasizes the need to take actions not only to alleviate public debt but also to place it on a descending pathway in the long-term. As analyzing the relationship between public debt to GDP ratio and economic growth has demonstrated to be necessary for governments to shape suitable fiscal policy guiding principles. It is recommended that the government is permitted to accumulate debt to no more than $78 \%$ of GDP; otherwise it will exert a negative effect on the economy.
\end{abstract}

Keywords: Co-integration, Economic Growth, Public Debt, FM-OLS, Non-linearity

\section{Introduction}

The relationship between public debt and economic growth is a major concern for policymakers. Empirical evidence has revealed that high public debt levels are negatively associated with economic growth. It is demonstrated that there are several channels through which public debt is likely to impede long-term growth. First, tax climbs required to service a higher public debt would crowdout private investments. Second, increasing public debt will stimulate an increase in long-term sovereign interest rates in a non-linear manner, as the probability of default increases. High long-term interest rates decrease productive public investments and crowd-out private investments by increasing the cost of capital [1].

However, the main debate among public debt economists concerning whether public debt accumulation at definite levels stimulates economic growth. As such a number of economic schools of thought have proposed the non-linear approach that the relationship between public debt and economic growth follows an inverted U-shaped in the sense that it turns out to be relevant merely after a definite threshold has been reached (see $[2 ; 3 ; 1]$ ).

Given the continual increase of public debt in Jordan lately which is an outcome of the combination of the following interrelated issues: the global financial crisis of 2008, Arab spring regional disturbances, energy crisis, closure of trade 
routes resulting in an actual economic restriction, and security costs that has put a significant pressure on Jordan's economic and fiscal drive which reduced the average real growth rate to about $2.0 \%$ as reported by the Jordanian Department of Statistics in 2018. Furthermore, Jordan's total public debt has increased at a rate surpassing economic growth, which has reached above $94 \%$ of GDP as reported by the Jordanian Ministry of Finance in 2018. The accumulation of such substantial burden of public debt has placed a financial distress on the public sector and has become a major concern for the Jordanians, which have placed pressures on the Jordanian government to restructure its public debt and privatize and enhance the collection of tax revenues.

The aim of this study is to investigate the long-run relationship between public debt and economic growth in Jordan using time series data over the period 1980 - 2018, within a standard neoclassical growth model, the adopted estimation approach is the fully modified ordinary least squares (FM-OLS) method. The contribution of the study to the literature is twofold. First, the relationship is investigated by applying linear specification with the inclusion of the latest years' data to capture the economic consequences of a regime of high and potentially persistent public debt. Second, a non-linear specification is also applied to assess whether an inverted U-shaped relationship does exist between public debt and economic growth in the long-run; as well as determining the optimal threshold of public debt in Jordan, beyond which public debt will start having a negative effect on economic growth.

The remainder of this study is organized as follows: Section 2 includes the study's theoretical and empirical literature on the relationship between public debt and economic growth. Section 3 describes data and provides an overview of the empirical models applied. In Section 4 the study's results are presented. Section 5 concludes by the policy implications.

\section{Literature Review}

This study surveys the theoretical literature and the recent empirical literature on the association between public debt and economic growth.

\subsection{The Theoretical Literature}

Government might accumulate public debt to provision public investments in physical infrastructures and human resources by public spending in education and health. Public debt can grow in such circumstances to avoid distorting taxes fluxes [4]; consequently, public debt can serve as means of delaying taxation that way reducing current distortions [5].

The theoretical economics literature studying relationship between public debt and economic growth can be divided into three major approaches, the Keynesian school, the neoclassical school, and the approach based on the Ricardian equivalence theorem.

The Keynesian approach suggests that during a recession with a high level of unemployment an expansive fiscal policy resulting in growing budget deficit and public debt increases the aggregate demand through the budgetary multiplier mechanism and hence results in a greater growth rate. Furthermore, indebtedness might also lead to investments, for instance infrastructural developments that may expand aggregate supply and employment level as well [6]. The Keynesian economists claim that, given that the recession is continuing, it is actually counterproductive to reduce government deficits since that can magnify the negative effect of the crisis [7]. It is noteworthy that while on the one hand Keynes suggested that the intervention assumed by the government should be increased during an economic recession to overcome the reduced aggregate demand, on the other hand, it is not debt and deficit which directly lead to accelerated economic growth, as it might be concluded, but it is the properly structured fiscal stimulus, expanding mainly human resources and other physical infrastructure, which causes the acceleration of economic growth.

In contrast to the Keynesian perspective, the neoclassical theory argues that increasing public indebtedness is definitely detrimental, because a slack fiscal policy increases current consumption, which leads to the decline of the savings rate. As a result, the interest rates need to rise, which in sequence will lead to a decline in investments and a deceleration of economic growth [8-10].

The conclusions of Elmendorf and Mankiw are aligned with the arguments of previous two perspectives; they find evidence that public debt does stimulate aggregate demand and output in the short- run but crowds out investment in the long-run [11].

In contrast to the previous two perspectives, the Ricardian equivalence proposition emphasizes that indebtedness does not affect economic growth. The theorem proposes that at the time when fiscal stimulus takes place and as a result the budget deficit is growing and government indebtedness is accelerating, market agents organize for a future periods of severity procedures and tax rises, and consequently they shift their emphasis from consumption and investment to increasing savings rate, which neutralizes the impact of the demand stimulating fiscal policy [12].

\subsection{The Empirical Literature}

The empirical literature is delineated along two approaches of modeling the relationship between public debt and growth; one approach deals with the linear effects and the other relates to the non-linear effects of public indebtedness on growth.

The negative long-term effect of public debt on the economic growth was confirmed by the empirical results of a large strand of studies (see $[13,14,1,15])$. Depending on the empirically estimated results through applying linear specifications, these studies cautioned the governments about the severity of public debt and confirmed that it should be carefully controlled.

The study of Kumar and Woo presented the first econometric evidence on the impact of initial high public 
debt on subsequent growth of real GDP per capita in a panel of advanced and emerging economies for the period of 19702008 by carefully applying various econometric techniques; their evidence strongly suggested an inverse relationship between initial debt and subsequent growth, controlling for other determinants of growth: on average, a 10 percentage point increase in the initial debt to GDP ratio is associated with a slowdown in real per capita GDP growth of around 0.2 percentage points per year [1].

The impact of growing debt levels on growth is investigated in a study that provided a thorough analysis of the dynamics of government debt and economic growth by exploring a considerably large worldwide sample covering 122 countries over the period 1960-2009. This study found a negative relationship between government debt and growth. The point estimates of the range of econometric linear specification suggest a 10-percentage point increase in the debt-to-GDP ratio is associated with 23 basis point reduction in average economic growth [16].

On the subject of the non-linear effect of debt on growth, where scholars have argued that the relationship follows an inverted U- shaped affiliation, whereby at certain low levels debt stimulates economic growth while at high levels the relationship is harmful to growth (see $[2,3,1]$ ). A large number of empirical papers found that the relationship between debt and growth is non-linear and characterized by the presence of a threshold above which debt starts having a negative effect on economic growth. The challenge that these studies bring is the issue of estimating the exact threshold for the inverted U- shaped relationship.

Considering other determinants of growth and applying quadratic and spline functions to a sample of 93 developing countries over the period 1969-1998, a study found that on average the external debt had an adverse effect per capita growth rate at ratios extending between 35 to 40 percent of GDP. The authors also stated that for the average country in the study, doubling the level of debt reduces economic growth by about 0.5 to 1 percentage point [2]. Similarly, another study found that when non-linearity is detected, the negative nonlinear impact kicks in at much lower levels of public debt that extend between $20 \%$ and $60 \%$ of GDP [3].

The seminal contribution of Reinhart and Rogoff that they analyzed through applying simple correlation statistics the associations of public debt and the long-term real GDP growth rate in a sample of 20 developed countries over a very long period 1790 - 2009; they found that the relationship between government debt and long-term growth rate is weak for debt to GDP ratios under a threshold of $90 \%$ of GDP; while above $90 \%$, the median growth rate falls by one percent and the average growth rate falls considerably more [14]. A similar change in the behavior of GDP growth in relation to the debt ratio was also found by Kumar and Woo who used dummy variables for predetermined ranges of debt to show non-linear effects in a sample of emerging and advanced economies. They found that only very high levels of debt, above 90 percent of GDP, have a significant and negative impact on growth; not surprisingly, they found that the negative effect was greater on emerging than advanced economies [1].

Expressing growth with a quadratic functional form of debt in a sample of 12 European countries over the period 1970-2008; a significant evidence of a concave relationship was found. The estimated debt turning point was found at about 90 to $100 \%$ of GDP and opined that economic growth is adversely affected after that debt to GDP threshold is reached [15]. The threshold was found to be between 60 to $70 \%$ of GDP for advanced economies [17]. Recently, a study found the threshold for Malaysia to be 55\% of GDP [18].

\section{Methodology}

\subsection{Study Sample and Variables Description}

The empirical analysis is based on annual data referred to the period 1980-2018, yielding thus for 39 data entries per variable considered. The data will be extracted from the Central Bank of Jordan yearly statistical series, and World Development Indicators (WDI) of World Bank Data Bank.

Real GDP growth (annual\%) (YG): The annual percentage growth rate of GDP (at Basic Prices) based on constant local currency, indexed at 1994-GDP deflator.

Gross fixed capital formation growth (annual\%) (GFCF): Average annual growth of gross fixed capital formation based on constant local currency. As a proxy for annual fixed capital accumulation for a particular country that consists of outlays on additions to the fixed assets of the economy plus net changes in the level of inventories.

Total labor force growth (annual\%) (LG): Annual labor force growth rate expressed as a percentage, Labor force comprises people ages 15 and older who supply labor for the production of goods and services during a specified period. It includes people who are currently employed and people who are unemployed but seeking work as well as first-time jobseekers.

Openness of trade (\% of GDP) (OT): Trade is the sum of exports and imports of goods and services measured as a share of gross domestic product.

Total public debt (\% of GDP) (TD): The total government gross debt is the sum of outstanding external public debt and outstanding domestic public debt, measured as a share of gross domestic product.

The set of growth determinants contains gross fixed capital formation growth, labor force growth rate, and openness of trade. Gross fixed capital formation and labor force growth rate reflect the positive impact of physical and human capital accumulation on economic growth, respectively. Trade openness is also posited to boost productivity through transfer of knowledge and efficiency gain. However, the economic theory suggests a negative effect of total public debt to GDP ratio on economic growth.

In order to control for the effect of the two financial crises on real GDP growth rate during the study period, two dummy variables are introduced as explanatory variables to capture the effects of Jordan's financial crisis during 1989-1990 and 
the global financial crisis during 2008-2009. The study uses the 2-year definition of crises, which involve two observations per crisis; the crisis dummy variable is taking on the value of one if the observation takes place during a financial crisis and the value of zero otherwise.

\subsection{Empirical Models}

This study relies on theoretical arguments and empirical considerations in modeling the debt-growth relationship adopting both linear and non-linear specifications:

\subsubsection{Linear Specification}

Our econometric specification is based on a Solow growth

$$
y g_{t}=\beta_{0}+\beta_{1} T D_{t}+\beta_{2} g f c f_{t}+\beta_{3} l_{t}+\beta_{4} o t_{t}+\beta_{5} D 1989+\beta_{6} D 2008+\varepsilon_{\mathrm{t}}
$$

Where, YG is annual real GDP growth rate, TD is the outstanding gross total public debt to GDP ratio, GFCF is gross fixed capital formation growth rate, $\mathrm{LG}$ is labor force growth rate, and OT is openness of trade. D1989 \& D2008 are financial crisis dummy variables to control for 1989 financial crisis and 2008 global financial crisis, respectively.

$\beta 0$ represents the intercept, $(\beta 1, \beta 2, \beta 3, \beta 4, \beta 5, \beta 6)$ are coefficients to be estimated, and $\varepsilon$ represents random error term.

The coefficients of growth determinants variables are expected to be positively signed, while the debt variable coefficient is almost always negatively signed and are significant. Similarly, the coefficients of the financial crisis dummy variables are expected to be negative, as revealed by the previous studies.

\subsubsection{Non -Linear Specification}

In the debt-growth dynamics literature there are theoretical reasons suggesting that such a linear specification might be insufficient to identify the actual impact of debt on growth, as the relation is likely to be nonlinear, i.e. the effect of debt could be positive at low levels of debt and turns out to be negative when the public indebtedness become excessive.

The study investigates the nonlinearity of the debt-growth relationship by considering a specification that accounts for the polynomial trend of the debt to GDP variable which introduces the smooth transition around a turning point in debt to GDP level. Following the modeling approach of the previous studies such as, Checherita and Rother, and Eberhardt and Presbitero [15, 19]; equation (1) has been transformed to formulate the following quadratic specification by introducing a squared term of the debt to GDP ratio (TDS) as an additional explanatory variable:

$$
y g_{t}=\alpha+\delta X_{t}+\beta T D_{t}+\gamma T D S_{t}+\varepsilon_{t}
$$

Re-writing the above equation in a more specific form, we have:

$$
y g_{t}=\beta_{0}+\beta_{1} T D_{t}+\beta_{2} T D S_{t}+\beta_{3} g f c f_{t}+\beta_{4} l g_{t}+\beta_{5} o t_{t}+\varepsilon_{t}
$$

Provided that the coefficient of debt (TD) is positive and regression model augmented by a debt stock term. Following the modeling approach of previous studies such as Pattillo et al. and Swamy [2, 16]; our specification assumes that the growth for a country conforms to a linear relationship over the period $\mathrm{t}$ :

$$
y g_{t}=\alpha+\delta X_{t}+\beta T D_{t}+\varepsilon_{t}
$$

Where, YG is annual real GDP growth rate, TD is the outstanding gross total public debt to GDP ratio, and $\mathrm{X}$ is a vector of Solow explanatory variables including GFCF, LG, and OT.

Re-writing the above equation in a more specific form, we have:

the coefficient of debt squared (TDS) is negative, this quadratic specification would support a non-linear debt growth relationship follows an inverted U-shaped pattern, where the peak of the quadratic function identifies the level of debt at which the marginal impact of debt on growth becomes negative. The threshold is determined by partially differentiating equation (3) with respect to debt and equating the first order condition to zero.

\subsection{Empirical Results}

Applying suitable econometric methodology for analyzing time series data is very essential since using inappropriate method of estimation or applying wrong specification of the model results in biased and unreliable estimates. Mainly, the selection of the time series analysis method is based on the results of the unit root test which describe the time series data stationary of each variable. Methods usually used to investigate the stationary time series cannot be applied to investigate non-stationary series. Similarly, additional considerations are taken when variables used in the analysis are mixed in nature, i.e., some of the variables are stationary and others are non-stationary. Consistent with the prescribed methodological framework, the analysis starts with exploring the properties of time series; the conventional unit root test is carried out in the next section.

\subsubsection{Unit Root Test Result}

The unit root test on the series is carried out separately at level data and at first difference by using the common unit root test method Augmented Dickey Fuller (ADF), the results are shown in Table 1.

Table 1. ADF test results.

\begin{tabular}{llllll}
\hline \multirow{2}{*}{ Variable } & Level & \multicolumn{3}{c}{ First difference } & \multirow{2}{*}{ Results } \\
\cline { 2 - 5 } & t-stat & p-value & t-stat & p-value & \\
\hline YG & -4.32 & 0.0077 & -9.41 & 0.0000 & I $(0)$ \\
GFCF & -5.12 & 0.0009 & -6.80 & 0.0000 & I $(0)$ \\
LG & -5.13 & 0.0009 & -5.52 & 0.0004 & I (0) \\
OT & -2.04 & 0.5611 & -5.05 & 0.0011 & I $(1)$ \\
TD & -2.61 & 0.2753 & -3.59 & 0.0455 & I (1) \\
\hline
\end{tabular}

The results of augmented Dickey-Fuller (ADF) test for time series data stationary show that the series of real GDP 
growth rate (YG), gross fixed capital formation growth rate (GFCF), and labor force growth rate (LG) are stationary at the level data. However, the series of openness of trade (OT), and total public debt (TD) become stationary at first difference.

\subsubsection{Co-integration Tests Results}

As mentioned in the previous section, the choice of the estimation method is mainly determined by the data stationary, with reference to the conducted unit root test results presented in the previous section, it is shown that the series included in the linear specification model are integrated of different orders I (0) \& I (1), then it follows to test for co-integration to determine whether there is long-run relationship between the variables. Engle- Granger cointegration test is adopted to determine whether there is a cointegration between the variables [20].

Table 2. Engle- Granger Co-integration Test Result.

\begin{tabular}{lll}
\hline & Value & Probability \\
\hline Engle-Granger tau-statistic & -6.71 & 0.0045 \\
Engle-Granger z-statistic & -41.53 & 0.0042 \\
\hline
\end{tabular}

As shown in Table 2, the results of Engle- Granger cointegration test indicate that there is co-integration among the considered variables of the linear model specification at a $1 \%$ significance level.

\subsubsection{Linear Specification Estimation}

As this study is concerned mainly with examining the long-run relationship between economic growth and public debt, the linear relationship between debt and economic growth is investigated by applying the method of fully modified ordinary least squares (FM-OLS) estimator proposed by Philips to provide optimal estimates of cointegrating regressions [21]. The method modifies least squares to account for serial correlation effects and the endogenous feedback effect in the explanatory variables that arise from the existence of a co-integrating relationship [22]. Hence equation (2) of co-integrating regression has been estimated by FM-OLS in order to attain unbiased estimates of the long-run relationship as the underlying explanatory variables are non-stationary processes. The FM-OLS has been demonstrated to be a fully efficient technique of the long-run equilibrium estimation (co-integration) relationship mainly in small samples [23]. The obtained results are presented in Table 3.

As shown in Table 3, all the coefficients of explanatory variables are with the priori expected signs and are statistically significant at $5 \%$ significance level or better. The Long-run coefficients on the gross fixed capital formation and openness of trade are positive, consistent with the economic theory, and are statistically significant at $1 \%$ significance level. Similarly, the long-run coefficient on the labor force growth rate is positive and statistically significant at $5 \%$ significance level.

The long-run coefficient on total public debt to GDP ratio is negative, consistent with the economic theory, and is statistically significant at $1 \%$ significance level. This implies that a 10-percentage point increase in total debt to GDP ratio is associated with a slowdown in real GDP growth rate of 0.32 percentage points in the long-run.

With respect to the crises dummy variables, both have the anticipated negative signs and are statistically significant, but with a greater magnitude of the financial crisis in 1989. Since in any event, a currency crisis seems to be quantitatively more important than a banking crisis for economic growth [24]; on average the reduction in growth associated with the financial crisis in 1989 was 0.095 percentage points of annual growth, whereas the financial crisis in 2008 was associated with a reduction of 0.045 percentage points of annual economic growth.

The R-squared implies that $70 \%$ of the variation in real GDP growth rate is explained by the specified model.

Table 3. Estimated long-run coefficients using the FM-OLS approach.

\begin{tabular}{llll}
\hline Dependent Variable: YG & & & \\
\hline Variable & Coefficient & t-Statistic & Prob. \\
\hline GFCF & 0.001296 & 5.78 & 0.0000 \\
LG & 0.187252 & 2.28 & 0.0292 \\
OT & 0.000705 & 3.33 & 0.0022 \\
TD & -0.032156 & -3.22 & 0.003 \\
D1989 & -0.095572 & -4.14 & 0.0002 \\
D2008 & -0.04503 & -2.88 & 0.007 \\
Constant & -0.014949 & -0.56 & 0.5764 \\
R-squared & 0.704266 & & \\
\hline
\end{tabular}

\subsubsection{Non -Linear Specification Estimation}

In the debt-growth dynamics literature, As it has been noted, there are theoretical reasons proposing that such a linear specification might be insufficient to identify the effect of public debt on economic growth, since the relation is expected to be nonlinear, i.e. The effect of debt could be positive at low levels of debt and become negative when total indebtedness become excessive. This suggestion is consistent with the results obtained in the linear specification section, where there is empirical evidence that on average, a 10-percentage point increase in the total debt to GDP ratio is associated with a slowdown in real GDP growth of 0.32 percentage points per year. Though the coefficient of total public debt is negative, its magnitude is immaterial in economic terms. Actually, the linear estimation would underestimate the effect by failing to capture the non-linear relationship between debt and growth and as a result estimating a flatter slope even when managing to capture a negative coefficient [2]. The equation (4) is estimated by FM-OLS, the obtained results are presented in Table 4.

As summarized in Table 4, the result of the model implies that the coefficient of debt term is positive and the coefficient of debt squared term is negative, as suggested by the economic theory, that indicates a highly statistically significant non-linear relationship between government debt and real GDP growth rate in the long-run which supports a debt -growth inverted U-shaped relationship. 
Table 4. Estimated long-run coefficients of quadratic debt using the FM-OLS approach.

\begin{tabular}{llll}
\hline Dependent Variable: YG & & & \\
\hline Variable & Coefficient & t-Statistic & Prob. \\
\hline GFCF & 0.001362 & 8.55 & 0.0000 \\
LG & 0.035726 & 0.66 & 0.5097 \\
OT & 0.000781 & 4.99 & 0.0000 \\
TD & 0.064016 & 2.47 & 0.0186 \\
TDS & -0.041009 & -4.70 & 0.0000 \\
Constant & -0.071592 & -2.66 & 0.012 \\
R-squared & 0.64164 & & \\
\hline
\end{tabular}

The debt to GDP turning point of this concave relationship is $78 \%$ on average. This means that, on average government debt to GDP ratios above such threshold would have a negative effect on real economic growth in the long-run. The value of R-squared is 0.64 for the quadratic equation, suggesting that accepting the non-linear relationship is reasonable.

The optimal threshold is derived based on the result obtained by partially differentiating the following equation with respect to debt and equating the first order condition to zero: $\mathrm{yg}_{\mathrm{t}}=0.064016 \mathrm{td}_{\mathrm{t}}-0.041009 \mathrm{td}_{\mathrm{t}}^{2}$

$\partial \mathrm{yg} / \partial \mathrm{td}=0.064016-(2 * 0.041009) \mathrm{td}_{\mathrm{t}}$, let it equal zero

$0=0.064016-0.082018 \mathrm{td}_{\mathrm{t}}$, thus the optimal threshold $\mathrm{tdt}$ equals $0.064016 / 0.082018=78 \%$.

The non-linear relationship between debt and growth is plotted as shown in Figure 1.

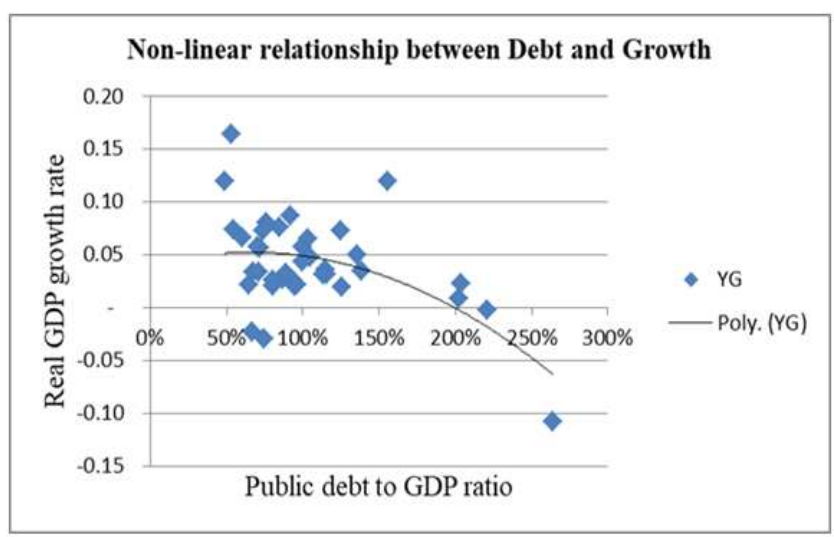

Figure 1. Plot of the real GDP growth rate as a quadratic function of public debt.

As shown in Figure 1, the non-linear trend line added to the scatter plot reveals that additional debt lower than 78 percent of debt to GDP ratio has a positive effect on economic growth, while in the range above this value, the effect is negative.

\subsubsection{Robustness of the Polynomial Functional Form}

The robustness of the results is evaluated by comparing the coefficient estimates of the specifications by adding or removing explanatory variables. Yet, one may be concerned that the use of different powers of the debt term might influence the results. In addition to the quadratic form of public debt to GDP ratio, other polynomial functions are checked by applying powers higher than one (in increments of 0.2 ) up to the power 3. Applying different polynomial forms does not change the study conclusion that is the relationship continues to be concave (see figure 1) and the debt turning point remains approximately between $75 \%$ and $78 \%$ of GDP that implies the robustness of the findings. The results are presented in Table 5.

Table 5. Different functional forms and the resulting debt to GDP ratio turning points.

\begin{tabular}{lll}
\hline Powers & Turning Point & Coefficient Power-term \\
\hline 1.2 & $75.20 \%$ & $-0.37693^{* *}$ \\
1.4 & $76.07 \%$ & $-0.15945^{* *}$ \\
1.6 & $76.85 \%$ & $-0.091089^{* *}$ \\
1.8 & $77.52 \%$ & $-0.059024^{* *}$ \\
2 & $78.05 \%$ & $-0.041009^{* *}$ \\
2.2 & $78.45 \%$ & $-0.029774^{* *}$ \\
2.4 & $78.67 \%$ & $-0.022272^{* *}$ \\
2.6 & $78.68 \%$ & $-0.017019^{* *}$ \\
2.8 & $78.47 \%$ & $-0.013211^{* *}$ \\
3 & $77.95 \%$ & $-0.010377^{* *}$ \\
\hline
\end{tabular}

The significance level of the power-term coefficients is also indicated $(* * 1 \%)$.

The table displays different polynomial forms of the economic growth rate as a function of public debt to GDP ratio, as well as the resulting debt turning points and the power terms coefficients, as the power approaches 3, the coefficient of the higher power term remains significant at $1 \%$ significance level but the magnitude turns out to be very small as the power increases. The fifth row (power 2) represents the basic model of the study with estimated coefficients for debt and debt squared of equation (4).

\section{Results}

Given the continual increase of public debt in Jordan lately, this study attempts to provide an analytical answer to an important economic concern that requires increasing attention and efforts of the policy makers, international organizations, lending institutions, and the public: the relationship between public debt and growth in Jordan; Is there nonlinearity evidence?

Toward this purpose, the study begins with a standard growth framework augmented with a public debt indicator measured as a ratio of GDP, in addition to utilizing several econometric specifications, linear and quadratic, to examine the relationship between debt and growth. The study applies fully modified ordinary least squares (FM-OLS) to investigate the presence of a long-run equilibrium.

Empirical evidence, based on econometric analysis of Jordan's debt and economic growth performance over the past 39 years, strongly suggests an inverse relationship between debt and growth, on average, a 10 percentage point increase in the total debt to GDP ratio is associated with a slowdown in real GDP growth of 0.32 percentage points per year.

There is an evidence of non-linearity, with only high levels of debt exceeding 78 percent of GDP, having a significant negative effect on growth. The study emphasizes the need to 
take actions to not just alleviate public debt but to place it on a descending pathway in the long-term. It is recommended that the government is allowed to accumulate debt to nomore than $78 \%$ as well.

\section{Policy Implications}

The study results have important policy implications for economic growth in Jordan. The following policy implications are highly recommended, first, the negative debt-growth relationship supports the argument that public debt need to be prepared based on conditions that are consistent with maintaining debt sustainability, and also on conditions that creates growth surpluses in the long-term by concentrating on investments in valued physical infrastructure and education. In other words, the accumulation of debt should be used to finance investments that assist the development requirements of the country in opposition to meet short-term financial needs of government. Consequently, public debt should be utilized in crowding-in and not crowding-out investments.

It is also recommended that balancing the fiscal budget to efficiently decrease the accumulation of public debt. Cautious fiscal management should constantly be executed through the steady remodeling of the public sector and restructuring the systems of expenditure control, revenues collection and management processes, and debt management strategies. In addition to structural-fiscal reforms that aim enhancements in the credibility of budget, in terms of preparation and execution, are also highly required.

Specifically, with regard to debt management strategy, Jordanian policy-makers should effectively participate in monitoring Jordan's public debt position, by taking the needed considerations to utilize it into productive use and contained with optimal range, public debt would continue to have positive impact on economic growth. Furthermore, close consideration should be given to avoiding the risk of being trapped in the debt overhang condition.

Finally, implementing the required structural reforms will enhance the productivity of investments along with macroeconomic stability. Such reforms intended for achieving fiscal and debt sustainability must be complemented by strategies to improve national productivity and competitiveness, and as a result a sustainable economic growth would be achieved.

\section{References}

[1] Kumar, M. and Woo, J. (2010). Public Debt and Growth. IMF Working Paper 10/174.

[2] Pattillo, C. Poirson, H. and Ricci, L. (2002). External Debt and Growth. IMF Working Paper 02/69, 1-47.

[3] Egert, B. (2015), Public debt, economic growth and nonlinear effects: Myth or reality? Journal of Macroeconomics, 43: 226238 .
[4] Barro, R. (1979). On the Determination of the Public Debt. Journal of Political Economy, 87, 940-947.

[5] Martin, F. M. (2009). A positive theory of government debt. Review of economic Dynamics, 12, 608-631.

[6] Davidson, P. (2010), "Making Dollars and Sense of the US Government Debt", Journal of Post-Keynesian Economics, vol. 32, pp. 663-667.

[7] Charles, S., Dallery, T., and Marie, J. (2015). Why the Keynesian Multiplier increases during Hard Times: A Theoretical Explanation Based on Rentiers' Saving Behaviour. Metroeconomica, 66 (3), 451-473.

[8] Saint-Paul, G. (1992). Technological Choice, Financial Markets and Economic Development. European Economic Review, 36 (4), 763-781.

[9] Bernheim, D. B. (1989): A Neoclassical Perspective on Budget Deficit, Journal of Economic Perspectives, vol. 3, no. 2, Spring 1989, pp 55-72.

[10] Gumus, E. (2003). Crowding-Out Hypothesis versus Ricardian equivalance Proposition: Evidence from Literature, Osmangazi University Journal of Social Sciences, 4 (2), 2135 .

[11] Elmendorf, D. and Mankiw, N. (1999). Government Debt. Handbook of Macroeconomics, vol. 1 Part C, 1615-1669, North-Holland.

[12] Barro, R. (1989). The Ricardian Approach to Budget Deficits. Journal of Economic Perspectives, 3 (2), 37-54.

[13] Chudik, A., Mohaddes, K. and Pesaran, M. H. (2017). Is There a Debt-Threshold Effect on Output Growth? Review of Economics and Statistics, 99 (1), 135-150.

[14] Reinhart, C. M. and Rogoff, K. S. (2010). Growth in a Time of Debt. NBER Working Paper No. 15639.

[15] Checherita, C. and Rother, P. (2010). The impact of high and growing government debt on economic growth: An empirical investigation for the Euro Area. Working Paper Series No. 1237, European Central Bank.

[16] Swamy, V. (2015). Government Debt and Economic Growth Decomposing the Cause and Effect Relationship. Institute of Economic Growth, Delhi, Delhi, Online at http://mpra.ub.unimuenchen.de/64105/ MPRA Paper No. 64105.

[17] Baum, A., Checherita-Westphal, C., and Rother, P. (2012). Debt and growth: New evidence for the Euro Area. Working Paper Series No. 1450, European Central Bank.

[18] Baharumshah, A. Z., Soon, S., and Lau, E. (2017). Fiscal sustainability in an emerging market economy: when does public debt turn bad? Journal of Policy Modelling, 39, 99113.

[19] Eberhardt, M. \& Presbitero, A. (2015). Public debt and growth: Heterogeneity and non-linearity. Journal of International Economics, 97, 45-58.

[20] Engle, R. F. and Granger, C. W. J.(1987). Cointegration and Error Correction: Representation, Estimation, and Testing. Econometrica, 55, 251-276.

[21] Philips, P. C. B. and Hansen, B. E. (1990). Statistical Inference in Instrumental Variables Regressions with I (1) Processes. The Review of Economic Studies, 57, 99-125. 
[22] Philips, P. C. B. (1995). Fully modified least squares and vector autoregression. Econometrica, 63 (5), 1023-1078.

[23] Hargreaves, C. P. (1994). Non-stationarity Time-Series Analysis and Cointegration. Oxford University Press, UK.
[24] Barro, R. (2003). Determinants of economic growth in a panel of countries. Annals of Economics and Finance, 4 (2), 231274. 